University of Wollongong

Research Online

Faculty of Law, Humanities and the Arts Papers (Archive)

Faculty of Arts, Social Sciences \& Humanities

$1-1-2018$

Menzies and Howard on themselves: Liberal memoir, memory and myth making

Zachary Gorman

University of Wollongong, zkkg318@uowmail.edu.au

Gregory C. Melleuish

University of Wollongong, gmelleui@uow.edu.au

Follow this and additional works at: https://ro.uow.edu.au/lhapapers

Part of the Arts and Humanities Commons, and the Law Commons

Research Online is the open access institutional repository for the University of Wollongong. For further information contact the UOW Library: research-pubs@uow.edu.au 


\title{
Menzies and Howard on themselves: Liberal memoir, memory and myth making
}

\author{
Abstract \\ This article compares the memoirs of Sir Robert Menzies and John Howard, as well as Howard's book on \\ Menzies, examining what these works by the two most successful Liberal prime ministers indicate about \\ the evolution of the Liberal Party's liberalism. Howard's memoirs are far more 'political', candid and \\ ideologically engaged than those of Menzies. Howard acknowledges that politics is about political power \\ and winning it, while Menzies was more concerned with the political leader as statesman. Howard's \\ works can be viewed as a continuation of the 'history wars'. He wishes to create a Liberal tradition to \\ match that of the Labor Party. \\ Disciplines \\ Arts and Humanities | Law \\ Publication Details \\ Gorman, Z. \& Melleuish, G. (2018). Menzies and Howard on themselves: Liberal memoir, memory and \\ myth making. History Australia, 15 (1), 7-22.
}

This journal article is available at Research Online: https://ro.uow.edu.au/lhapapers/3442 


\section{Menzies and Howard on themselves: Liberal memoir, memory and myth making}

This article compares the memoirs of Sir Robert Menzies and John Howard, as well as Howard's book on Menzies, examining what these works of the two most successful Liberal Prime Ministers indicate about the evolution of the Liberal Party's liberalism. Howard's memoirs are far more 'political', candid and ideologically engaged than those of Menzies. Howard acknowledges that politics is about political power and winning it while Menzies was more concerned with the political leader as statesman. Howard's works can be viewed as a continuation of the 'History Wars'. He desires to create a Liberal tradition to match that of the Labor Party.

Keywords: Menzies, Howard, Liberal Party, liberalism, memoirs.

Introduction: Menzies and Howard

Robert Menzies and John Howard are Australia's two longest serving prime ministers. Their stories lie at the heart of how the Liberal Party of Australia has envisaged itself, its history and its role in the political life of the country. Both politicians wrote memoirs aimed at shaping their legacy for both historians and the general public. Menzies' memoirs are scattered and incomplete; Howard's are comprehensive and purposeful. This paper examines these memoirs, as well as Howard's book on Menzies, as a means of understanding the liberalism of the Liberal Party and how it has changed in recent times. While Menzies' memoirs avoid ideological stridency and lack a comprehensive political narrative, Howard has constructed an inherently political life-story, and provided a similar political narrative for 
Menzies. It concludes that Howard is making a conscious attempt to construct a Liberal pantheon in which he and Menzies can be remembered as great leaders, and thereby compete with what he views as a well-developed Labor mythology.

There is a considerable literature on Menzies including a two volume biography written by Alan Martin ${ }^{1}$, Judith Brett's own work on both Howard and Menzies and a biography of Howard by Wayne Errington and Peter van Onselen. ${ }^{2}$ Only Brett, however, attempts a comparison of Howard and Menzies in her introduction to the second edition of Robert Menzies' Forgotten People. Here, Brett claims that Howard was 'the most creative Liberal political leader since Menzies'. Continuing, she says that

both men re-worked their inherited political tradition to respond to new political and social circumstances. Menzies took the idea of the Forgotten Class and turned it into the Forgotten People, thus bypassing Labor's classed-based and collectivist politics with a confidently virtuous, independent individualism. Howard took the core Australian Liberal belief that, unlike Labor, Liberals were free of vested interests and so able to represent the interests of the nation as a whole and turned it into a powerful vernacular nationalism. ${ }^{3}$

If Brett is correct, then exploring the connections between Howard and Menzies is crucial for an understanding of how the liberalism of the Liberal Party has evolved over the seventy odd years which have passed since its founding. A key to an appreciation of that connection lies in an exploration of both Menzies' and Howard's self-perception as expressed in their memoirs and other post-retirement writings. This piece will argue that Howard has been

\footnotetext{
${ }^{1}$ A.W. Martin, Robert Menzies: A Life, Volume 1, (Melbourne: Melbourne University Press, 1993), A.W. Martin, Sir Robert Menzies: A Life, Volume II, (Melbourne: Melbourne University Press, 1999).

2 Judith Brett, Robert Menzies' Forgotten People, $2^{\text {nd }}$ Edition, (Melbourne: Melbourne University Press, 2007), Judith Brett, Australian Liberals and the Moral Middle Class: from Alfred Deakin to John Howard (Cambridge, 2003), Wayne Errington \& Peter van Onselen, John Winston Howard: The Biography (Melbourne: Melbourne University Press, 2007).

${ }^{3}$ Brett, Robert Menzies' Forgotten People, 11.
} 
involved in a deliberate attempt to construct a mythology for the Liberal Party, a task thought unnecessary by the Party's less ideological founder, and that this reflects important changes which have taken place both within the party and in the wider political culture.

Why then do former political leaders write memoirs and what purpose are they meant to fulfil? In essence memoirs are acts of self-justification which attempt to both inform and shape historical memory. On occasion they can be confessional and self-deprecating, but more often they seek to exonerate the writer from wrongdoing and build up their achievements so that they are shown to be worth remembering. George Egerton, one of the few people to look specifically at political memoirs, has suggested that the term generally denotes:

the endeavor by a retired politician to recount the important political engagements of his or her career, to explain and interpret the choices made and forces encountered, to portray the relationships experienced in the course of political activity while assessing the qualities of cohorts, and perhaps to offer some precepts or wisdom to assist political successors. ${ }^{4}$

Australia has a sporadic tradition of political memoir. While a number of participants in the federation campaign left personal accounts of the event, notably Alfred Deakin, Bernhard Wise and Sir Robert Garran, few in the first half of the twentieth century did the same for every-day politics. Those memoirs that were produced are notably disappointing. The reminiscences of Sir George Reid, written in virtual exile in Britain during the First World War, are remembered for their dullness and lack of insight. ${ }^{5}$ Similarly, Billy Hughes's Crusts and Crusades contains very little political material. Hughes was concerned primarily with

\footnotetext{
${ }^{4}$ George Egerton, "Politics and Autobiography: Political Memoir as Polygenre", Biography: An Interdisciplinary Quarterly, 15. No. 3, (1992), 222.

${ }^{5}$ W.G. McMinn, George Reid (Carlton, 1989) 1.
} 
evoking an epoch in Australian history which had long passed, especially the early 1890s. He explains his reluctance to discuss his parliamentary colleagues in these terms:

But this would have meant telling stories out of school—a breach of that code by which I have been guided all my public life: for I have always regarded my fellow members, irrespective of their party affiliations as my honourable friends and colleagues. ${ }^{6}$

Hughes's second volume of memoirs, which are more focused on politics, are still anecdotal and largely recount humorous events. ${ }^{7}$

The first Federal politician of any note to present memoirs which were both comprehensive and candid was Sir Earle Page. Published in 1963, two years after the author's death, Page's Truant Surgeon is arguably the first of its kind in Federal Australian politics. In the preface Page suggests that he was inspired to write the book both because he felt that newspaper accounts failed to capture the underlying reasons for decisions and events, and because none of his contemporaries had left a first-hand account to overcome this deficiency. Over four hundred pages long, it does not shy away from discussing the workings of politics and is critical of many political figures, including Menzies. ${ }^{8}$

The puzzle of Menzies's memoirs

Menzies was, in many ways, closer to Hughes than he was to Page. His memoirs are remarkably non-political, in the sense of not focusing on the activity in which politicians engage to get things done. Menzies wrote his memoirs in two haphazard volumes. The first, Afternoon Light, was published in October 1967, less than two years after he retired from office. The title is meant to invoke the idea that Menzies is using his newly found leisure time

\footnotetext{
${ }^{6}$ W.M. Hughes, Crusts and Crusades (Sydney: Angus \& Robertson: 1948) vi.

${ }^{7}$ W M Hughes, Policies and Potentates. Sydney: Angus \& Robertson. 1950

${ }^{8}$ Earle Page, Truant Surgeon, edited Ann Mozley, (Sydney: Angus and Robertson, 1963) xi.
} 
to jot down a few memories of people and events in a relaxed and comfortable atmosphere. He uses the image of a warm afternoon to disarm his audience, insisting that he is not carrying out an act of 'wearisome' self-justification, but rather just recording what he can for the benefit of future historians. ${ }^{9}$ Unlike Page, Menzies felt that he was not up to writing history, though he similarly dismisses contemporary history as little more than newspaper material and gossip. Instead of writing anything comprehensive, Menzies limits himself to a few first-hand impressions to round out the image which future writers might form of him and the people he writes about. In this regard he stands in contrast to John Howard, who attempts in both his memoirs and book on Menzies to produce something more complete. Howard tells us that he undertook to write the latter at the suggestion of Geoffrey Blainey, specifically because of Howard's politicised perspective. Menzies' memoirs appear to be written in the style of what Menzies believed that one would expect from a retired English gentleman. Menzies idealised the English as embodying the essence of civilised behaviour. ${ }^{10}$ What follows this short introduction is as limited as the author suggested that it would be. There are some brief autobiographical details about Menzies' parents, some anecdotes about cricket and the law, and some observations on deceased prime ministers (to write about those still living would presumably overstep the bounds of privacy and acceptable behaviour). The rest is almost exclusively on international affairs, with a particular focus on the British Commonwealth and Australia's relationship with the United States. There are also quite blatant 'self-justifications' of Menzies' actions during the Suez crisis, and his long trip to Britain which precipitated the loss of the prime ministership in 1941. Menzies' priorities seem puzzling to someone using a nationalist paradigm; for Menzies, Empire, or Commonwealth, were as important as Australia. Hence, his attention was focused as much on the wider world, especially the British world, as on Australia. As B.A. Santamaria put it

\footnotetext{
${ }^{9}$ Sir Robert Menzies, Afternoon Light: Some Memories of Men and Events (Melbourne: Cassell, 1967) 4.

${ }^{10}$ Robert Menzies, “The English Tradition”, in his Speech is of Time (London: Cassell, 1958) 33-41.
} 
when Menzies died, and this is apparent in his discussion of the British Commonwealth in both volumes of his memoirs, Menzies appreciated that Britain's entry into the EEC would largely spell its end. 'He knew that he would be a stranger in the post-imperial world.' ${ }^{11}$

Contemporary reviewers did not know quite what to make of Afternoon Light. One reviewer complained that Menzies' outlook was 'legalistic and outdated', and suggested that it was difficult to know what he wanted to achieve by writing the volume in the first place. ${ }^{12}$ Writing in Labour History, Robert Cooksey dissected Menzies' attempt to place himself in 'line of apostolic succession from Churchill' and his deliberate attempt to overlook salient facts when dealing with Suez. Cooksey concluded by telling his readers not to buy the book but to wait for a decent biography of Menzies. ${ }^{13}$

The main reason the book met with such an indifferent response, apart from its somewhat disjointed nature, is because it says so little about Australian politics. Earle Page, rather than Menzies, seemed to appreciate his readers' appetite for 'politics'. The chapter on the formation of the Liberal Party, which Menzies himself had previously described as one of his two greatest political achievements along with maintaining a strong alliance with the Country Party, is a mere sixteen pages long. ${ }^{14}$ Menzies' primary concern seems to have been to paint himself as an international statesman exercising consideration and loyalty; any descent into the partisanship of domestic politics is largely a distraction. While he fails to give any substantial information on Harold Holt, his long-time deputy and prime minister at the time of the book's publication, Menzies goes into detail about his close personal relationships with

\footnotetext{
${ }^{11}$ B.A. Santamaria, Running the Show: Selected Documents: 1939-1996, ed. Patrick Morgan, (Melbourne: Melbourne University Press, 2008) 371.

${ }^{12}$ Trevor R. Reese, International Affairs Vol. 44, No. 2, (1968), 392.

${ }^{13}$ Robert Cooksey, Labour History, Issue 16, (1969), 59.

${ }^{14}$ Menzies, Afternoon Light, 281-296
} 
American Supreme Court Justice Felix Frankfurter and Secretary of State Dean Acheson. ${ }^{15}$ These intimate relationships with the great men of Menzies' age form the core of the book.

Regarding any prescriptions about contemporary political events and concerns for the future, Afternoon Light practically limits itself to issues relating to the British Commonwealth. Chapters entitled 'A Critical Examination of the Modern Commonwealth' and 'the Crown in the Commonwealth' are two of the longest in the book and amount to lamentations over the decline of Imperial ties, expressing a hope that in the future Commonwealth nations will respect each other's internal sovereignty. Menzies even offers a possible solution to the waning ties of the Commonwealth; a common attachment to the rule of law might replace the no-longer universal allegiance to the Crown and belief in parliamentary democracy. ${ }^{16}$ Such concerns overwhelm discussion of the Liberal Party or Menzies' rise to power.

The second volume, The Measure of the Years, was published in 1970. There were remarkably few reviews of this book, perhaps a symptom of the disappointment many felt when reading the first volume. Nevertheless, The Measure of the Years does improve on and correct, many of its predecessor's flaws. There are more anecdotes about cricket and Menzies' experiences practising law. There is a longish chapter, 'Looking Forward', which deals with Britain and the Commonwealth which confirms Santamaria's view that Menzies has a strong sense that his world has come to an end. ${ }^{17}$ The overwhelming focus is, however, on domestic issues. At the heart of the book are fourteen chapters describing the key achievements of Menzies' time in office and giving some details as to how they were carried out. There is still a significant focus on foreign policy, including the relationship with New Zealand, Defence

\footnotetext{
${ }^{15}$ Menzies, Afternoon Light, 309-315.

${ }^{16}$ Menzies, Afternoon Light 228-9.

${ }^{17}$ Sir Robert Menzies, The Measure of the Years (Melbourne: Cassell, 1970) 201-221.
} 
policy and Pacific policy, but there are also chapters devoted to Menzies' signature education reforms and the economic growth that characterised his time in office. ${ }^{18}$

Despite the domestic focus, Menzies is still reluctant to portray himself as a partisan politician. The achievements of his Government are generally described as gradual and considered reforms, rather than as great changes, or reforms, resulting from clashes with the Opposition. Even when discussing the defeat of Ben Chifley's attempt to nationalise commercial air travel, an issue laced with the ideological differences between Labor and Liberal, Menzies tries to portray himself as a gradual pragmatist. Menzies replaced Labor's single airline with regulations designed to ensure a two-airline policy which would give consumers a veneer of choice while avoiding a 'free-for-all' of competition which might lead to lapse maintenance standards.${ }^{19}$ Menzies seems keen to demonstrate that he is not an ideological demagogue. When dealing with reforms his Government introduced, Menzies is also always careful to acknowledge the role of others. For example, in educational matters, he states that 'without generous and enlightened co-operation by the States, our own record, particularly in the university field, could not have been achieved'. ${ }^{20}$ Here the acknowledgement of the States is perhaps of less importance than the insistent use of 'our' and the nod it gives to joint Cabinet responsibility.

Menzies believed that the conduct of politics over time had moved from a rationalist approach to one based on induction and careful empiricism. ${ }^{21} \mathrm{He}$ argued that politics has evolved away from strident ideological conflict to politicians and public servants implementing good policy grounded in facts. This was the era of the 'end of ideology', when

\footnotetext{
${ }^{18}$ Menzies, The Measure of the Years, 44-109.

${ }^{19}$ Menzies, The Measure of the Years, 138.

${ }^{20}$ Menzies, Afternoon Light, 97.

${ }^{21}$ Sir Robert Menzies, "Introduction”, to W.M. Hughes, The Case for Labor (Sydney: Sydney University Press, 1970) viii.
} 
Keynesianism and centrist politics looked to have conquered the western world. ${ }^{22}$ In the era after the fall of the 'Australian Settlement', that in which Howard's books were written, the general consensus that underpinned such a gradualist approach no longer exists. ${ }^{23}$ It is also doubtful whether the insatiable appetite of the modern media for conflict and controversy would now allow a government, be it Labor or Coalition, the luxury of presenting itself as the careful and moderate guardian of a consensual national interest.

Menzies only truly descends into partisanship over one issue, the Petrov affair. Even when dealing with this momentous event, crucial in precipitating the Labor Party split, he seems aggrieved to have to defend himself against his Labor critics. The chapter on Petrov is the longest in the book as Menzies seeks to dismiss allegations that he manipulated the event for political advantage. He begins by expressing his frustration that 'picturesque slander' had been able to take hold of the public memory, and explained the chapter was necessary in 'the interests of the people involved, and of accurate history'. ${ }^{24}$ He then provides an authoritative account of events laced with long extracts from official reports and Hansard. His account not only absolves him of any wrongdoing but criticises Dr Herbert Evatt, who died in 1965, for both Evatt's poor handling of affairs and his personal obsession with conspiracy. Menzies concludes by suggesting that his solid election victory in November 1955, long after Evatt's charges of conspiracy had been made, proved that the Australian public ultimately saw through his opponent's slander.

The failure of either of Menzies' memoirs to provide in-depth details of his political career and his refusal to portray himself as a strong advocate of liberalism appear puzzling, especially as he was the founder of a party which self-consciously called itself liberal rather

\footnotetext{
${ }^{22}$ Daniel Bell, The End of Ideology: on the exhaustion of political ideas in the fifties (New York: Free Press, 1960).

${ }^{23}$ Paul Kelly, The End of Certainty (St Leonards: Allen \& Unwin, 1992).

${ }^{24}$ Menzies, Afternoon Light, 154.
} 
than conservative. Consequently, they have been little used by scholars. The central primary source for scholars exploring Menzies as a politician who was motivated by a set of principles and ideals, are not his memoirs but his 'Forgotten People' broadcasts from the early 1940s. These demonstrate Menzies' political philosophy, and how he defined his beliefs in opposition to Labor. For that reason they have been far more useful for scholars who have attempted to understand Menzies as the founder of the Liberal Party. The broadcasts were the central subject of Judith Brett's work Robert Menzies' Forgotten People and they have been published in a volume edited by David Kemp. ${ }^{25}$ Brett, in particular, has demonstrated how Menzies aimed his central message towards the homes of a middle class defined by values such as hard work, independence and family. The 'Forgotten People' can be seen as the basis of a specifically 'liberal' political programme whereas the memoirs downplay ideology of any kind.

Menzies' memoirs and his 'Forgotten People' can be contrasted in terms of context and intent. In 1943 Menzies was out of office, his career drifting after he had been forced to resign from the prime ministership. In these circumstances he needed to turn to a partisan ideology in order to construct a raison d'etre and a path back into power. By the time Menzies was writing his memoirs he did not need to do anything. He had retired from office at a time of his own choosing after the longest and most successful reign of any Australian Prime Minister. His memoirs were almost an indulgence which he hoped would shape his image for posterity: they did not require appeals to ideology or partisanship. On certain issues they are still laden with ideology, particularly in relation to Empire, but this was at the author's discretion. Menzies did not present himself so much as a Liberal Party 'politician' as a statesman. That was what mattered to him.

\footnotetext{
${ }^{25}$ Brett, Menzies' Forgotten People \& Robert Menzies, The Forgotten People and other studies in democracy, ed. David Kemp, (Melbourne: Liberal Party of Australia, 2011).
} 
John Howard's Liberal memoirs

John Howard's memoirs, published as Lazarus Rising: a personal and political autobiography in 2010, are fundamentally different from those of Menzies. As the title implies, the book blurs the lines between the outward focus of traditional political memoir and the inward focus of modern day autobiography. Unlike Menzies, Howard constructs a full political narrative, excepting thematic chapters for his prime ministership. This difference between Menzies and Howard is to some extent a product of historical context. Menzies is still very much working in an older tradition of anecdotes and amusing stories. In the late twentieth century the growth of political biography and autobiography as popular genres meant that readers increasingly expected a 'political' narrative. Lazarus Rising provides such an account and is clearly intended to be a work aimed at a mass audience. It lacks any kind of explanatory introduction as can be found in Afternoon Light. By Howard's time it had become much more common for a successful politician to offer a personal account of their life after leaving office; no justification was required.

Lazarus Rising is essentially a 'political' autobiography; it is a personal story which works its way from early influences through to mature political success. Care is taken to explain how Howard came to hold his Liberal beliefs. Indeed, the first chapter is given the title 'The Source', suggesting quite explicitly the origin of Howard's philosophy and interest in politics. Howard holds up his parents, not just as exemplary people as Menzies had, but as explanatory tools for the autobiographical narrative. His father's experience as a small business owner, and particularly the way in which an arbitrary government decision hurt his business, are shown as defining moments in the making of Howard the politician. ${ }^{26}$ It is because Howard accepts his role as a partisan politician that he tries to explain how he came to be one, whereas Menzies tries to suggest that his actions were informed not by any

\footnotetext{
${ }^{26}$ John Howard, Lazarus Rising: a personal and political autobiography (Sydney: Harper Collins, 2010) p.20.
} 
ideology but by what was abstractly right. In part, this change reflects the fact that politics in Australia since the 1970s has become much more partisan; the resurgence of economic liberalism ended the idea, on the non-Labor side of politics, that governing had little to do with ideology.

In Afternoon Light Menzies deals briefly with his loss of the prime ministership in $1941 .^{27}$ He does so almost as an afterthought, in the last few pages of a longer chapter on the early days of World War Two. A sense of modest indignation is conveyed about how he could be betrayed after an absence necessary to push Australia's interests in Britain, but beyond a complaint about negative newspaper coverage, little explanation is given as to why Menzies' colleagues abandoned him. He says little about his earlier relationship with Joe Lyons and his resignation from the Lyons cabinet; he provides no reason for Earle Page's animosity towards him. Dealing with a similar scenario, Howard's loss of the Liberal leadership in 1989, Lazarus Rising is far more candid, and in the modern genre of political realism. Howard tries to give a proper explanation as to why he was removed, both through discussion of the personality clashes within the Liberal Party and media gaffes such as his comments on Asian immigration. ${ }^{28}$ Whether the explanation is adequate is debatable, but its existence demonstrates the author's commitment to an inherently political narrative.

Perhaps the starkest contrast between Menzies' memoirs and Howard's autobiography is how they deal with colleagues who are still alive. As previously mentioned, Menzies says little about living former colleagues. Howard has no such qualms in this area. While he generally avoids unnecessary attacks, the author of Lazarus Rising engages in honest assessment. This is particularly the case when Howard deals with his long-time deputy leader Peter Costello. The Costello Memoirs had been released in 2008 and one of that book's central themes were

\footnotetext{
${ }^{27}$ Menzies, Afternoon Light, 52-56.

${ }^{28}$ Howard, Lazarus Rising, .171-180.
} 
the tensions between Costello and Howard over when, and if, the latter would hand over the leadership of the Liberal Party. ${ }^{29}$ Lazarus Rising spends considerable time offering Howard's interpretation of these events. It devotes an entire chapter to justifying the fact that the leadership was not handed over, and insists that if the majority of the Liberal Party had wanted Costello to become leader Howard would not have stopped it from happening. ${ }^{30}$ Howard also mixes up past and present in his analysis; on more than one occasion he interrupts the historical account to make a connection with a contemporary political event. For example, when discussing the 1978 budget he delivered as Treasurer in the Fraser Government, Howard proceeds to criticise Julia Gillard for reversing much of 'the progress of the past 25 years' in relation to industrial relations. ${ }^{31}$

These differences between Menzies and Howard reflect a cultural shift in Australian politics over the last forty years. Politicians now accept their place as party politicians, and while political leaders may still maintain illusions that they are above politics, their primary identity is defined by their political allegiance. Despite Menzies' derision of the 'gossip column' nature of news-media in the 1960s, the public appetite for political intrigue and stories of internal party struggles has arguably only grown since the time when he was writing. ${ }^{32}$ Politics, in a public mind moulded by 'The Game of Thrones' and 'House of Cards' is meant to be Machiavellian. For that reason memoirists now feel not only able but obliged to write more about their personal struggles with fellow compatriots. This has led to politicians being willing to acknowledge the brutal realism of political life, as Howard does:

I was not removed as Liberal leader in favour of Peter Costello because the great majority of the Liberal senators and MPs never wanted that to happen. Politics is

\footnotetext{
${ }^{29}$ Peter Costello \& Peter Coleman, The Costello Memoirs (Melbourne: Melbourne University Press, 2008).

${ }^{30}$ Howard, Lazarus Rising, 599-625.

${ }^{31}$ Howard, Lazarus Rising, 107.

${ }^{32}$ Menzies, Afternoon Light, 1.
} 
relentlessly driven by the laws of arithmetic. If a political party thinks that its electoral arithmetic will be boosted by a leadership change, it will make that change, irrespective of the circumstances. ${ }^{33}$

Another difference between the 1960s and the present is the permanence of the party system. Menzies' career was as a member of the Nationalist Party, then the United Australia Party before he founded the modern Liberal Party in 1944. As a young man he would also have witnessed the birth of the Country Party. These shifting sands meant that non-Labor politicians were far less likely to develop strong emotional attachment to their political party than has since become the case. As a young man Menzies was heavily involved in the formation of the Young Nationalists, arguably the archetypical young party movement that successors have since been trying to emulate. ${ }^{34}$ Nevertheless, he did not grow up in the party system in the way subsequent politicians have. The Nationalist Party and the United Australia Party owed their existence more to the need to accommodate former Labor politicians than to a desire to implement a principled political programme. The Australian Labor Party has had great stability as a single Federal entity and trade unions have long acted as a training ground for Labor politicians. In contrast, it is only relatively recently that practising politicians have begun emerging from the Young Liberals. This reflects the fact that while the 'Liberals' went through four different parties in the first half century of the Commonwealth they have enjoyed an enduring structure since 1944. Howard was arguably one of the first products of this stable party structure. He is very much 'of the Liberal Party.' Menzies was there so long and had such an impact, that by the time he had gone there was no one who remembered what things had been like before him. As described in Lazarus Rising, Howard first took an interest in politics during the 1949 election where Menzies' Liberal Party won power for the first time. Howard subsequently joined the Earlwood branch of the Young Liberals at the

\footnotetext{
${ }^{33}$ Howard, Lazarus Rising, 600.

${ }^{34}$ Martin, Robert Menzies: A Life Volume 1, 75-8.
} 
tender age of eighteen. ${ }^{35} \mathrm{He}$ had a career as a solicitor, but throughout this time he was frequently acting as a campaign manager and engaging in other acts of politicking. Though he was not a political staffer as are many Young Liberals now, Howard grew up as a Young Liberal with a clear goal of entering politics, and thus it was only natural for the Liberal Party to be the central focus of his memoirs.

A stable political party has been matched by a more disciplined party machine. The nineteenth century liberal tradition emphasised individual conscience; and Judith Brett argues this still mattered with the formation of the Commonwealth Liberal Party in $1909 .{ }^{36}$ The fluid structure of non-Labor Parties prior to 1944 was matched by a greater independence of individual members. Billy Hughes, for example, moved in and out of the party, and in 1929 two Nationalists voted with the Opposition to bring down the Bruce-Page Government. 37 Menzies entered politics at a time when independence on the part of members was not entirely dead. Howard was a product of a much more disciplined party, a disciplined party created by Menzies. A disciplined party also requires a degree of ideological consistency. Howard understood that ideological consistency in terms of the Liberal Party as a 'Broad Church', combining social conservatism and economic liberalism; 'it was the party of Mill as well as Burke'. ${ }^{38}$ For Howard, politics is intrinsically ideological, it 'is above all else a battle of ideas. ${ }^{39}$ We must constantly revisit our philosophical moorings, to ensure that our goals have not been lost sight of.'

There is another personal difference in outlook between Menzies and Howard which affected how they wrote their memoirs. That is Howard's personal obsession with the contest over

\footnotetext{
${ }^{35}$ Howard, Lazarus Rising, 29.

${ }^{36}$ Judith Brett, "Class, Religion and the Foundation of the Australian Party System: A Revisionist interpretation”, Australian Journal of Political Science, 37, no. 1, (2002), 39-56.

${ }^{37}$ Geoffrey Sawer, Australian Federal Politics and Law 1901-1929 (Melbourne: Melbourne University Press, 1972), 310-12.

${ }^{38}$ Howard, Lazarus Rising, 213.

${ }^{39}$ John Howard. 'For a Principled Conservatism.' Dorchester Review. 3 (2013): 80-2.
} 
history and historiographical interpretations of the past. During much of Howard's time as prime minister, the 'history wars' raged. Central to the 'history wars' was the extent to which the atrocities committed against Aborigines cast a shadow over other achievements made since 1788. There was an explicit push from the right to fight against the 'black armband' view of Australian history which had allegedly set in during the Hawke and particularly the Keating era, in favour of a more positive appreciation of Australia's past. The term 'black armband' history had been coined by Geoffrey Blainey to refer to what he saw as an unfairly 'jaundiced' picture of Australia's past. ${ }^{40}$ Howard adopted Blainey's phrase and used it as a justification to project a new, or resurrect an old, glorified view of Australia's past. ${ }^{41}$ In doing so he gave tacit and occasionally explicit encouragement to the main right wing combatants of the history wars, Quadrant and Keith Windschuttle. ${ }^{42}$ Such a stance had a clear populist appeal, exaggerated by Howard's ability to play off the academic 'elites' who pushed the black armband view against his own relaxed and comfortable 'battlers'. ${ }^{43}$ Nevertheless, it also reflected beliefs which Howard unquestionably possessed. As a self-described 'Burkean conservative' he naturally looked towards the past for inspiration and stability, hence to dismiss what had gone before him went against his natural political instincts, which explains his opposition to an Australian republic. ${ }^{44}$.

As someone who had already waded into historical debates as prime minister, it was only natural that after his forced retirement Howard would write an autobiography with the intent of shaping how he was remembered. In an interview given at the time of the publication of Lazarus Rising Howard gave an explanation why he had written the book:

\footnotetext{
${ }^{40}$ Geoffrey Blainey, "Drawing up a balance sheet of our history", Quadrant, vol. 37, no. 7-8, July-August 1993 , $10-15$.

${ }^{41}$ John Howard, Sir Robert Menzies Lecture, 30/10/1996.

${ }^{42}$ Robert Manne, "The History Wars", The Monthly, November 2009, 15-17.

${ }^{43}$ Stuart Macintyre \& Anna Clark, The History Wars (Melbourne: Melbourne University Press, 2004) 2-4.

${ }^{44}$ John Howard, Address to the National Press Club, 11/9/2002, Howard, Lazarus Rising, 200.
} 
I wanted to tell the Australian public what motivated me in public life and I wanted to give an account of the important things that I'd done in public life, and to deal with all of the controversial issues and leave people in no doubt. I was very privileged to have been prime minister for so long and I wanted to give the Australian people an account of that. I also felt I had an obligation to deal with the personalities I encountered. If you're in a senior position in a political party, you'll inevitably have close relations and those relations, on occasion, run into difficulties. What I tried to do is address in an objective fashion my relationship with a number of people on my side. ${ }^{45}$

There are a number of interesting phrases in this explanation. Perhaps the key one is to 'leave people in no doubt'. This goes beyond self-justification of decisions made, more explicitly it seeks to pre-empt historical debates and shut them down. Ultimately, Howard wants to take as much control as possible over how he is remembered. This may also indicate a fear, arising out of the history wars, that his detractors might gain control of his public memory. Whether such a goal is achievable is another matter entirely. People who disagree with a politician are going to disregard professed motives, preferring to project their own interpretations on to events. Likewise, historians are unlikely to take any statement at face value. They might use it as a starting point, but they will check the facts against other sources; nothing might please them more, professionally, than to discover a contradiction between a Howard statement and other evidence. Nevertheless, Deakin's account of the coming of Federation, although unpublished in his lifetime, indicates how a politician can mould the views of future generations. ${ }^{46}$ When such limitations of persuasion are factored in, the

\footnotetext{
${ }^{45}$ John Howard . \& Imre Salusinszky, 'Relaxed and Comfortable', Australian, 22 October, 2010.

${ }^{46}$ Alfred Deakin, “And Be One People”: Alfred Deakin's Federal story, Int. Stuart Macintyre, (Melbourne: Melbourne University Press, 1995).
} 
question becomes who Howard hopes to be speaking to with Lazarus Rising. Posterity certainly includes future historians, but he is seeking to influence a much wider group.

Howard hopes to create a legacy for the 'Howard years' in the popular memory. This legacy includes central reforms such as the GST and Australian Workplace Agreements, tenets of foreign policy such as a strengthened alliance with the United States and increased engagement with Asia, as well as more subtle changes to indigenous policy and the administration of welfare. They key achievement which Howard invokes is his Government's record of economic growth. He is keen to showcase the fact that according to any basic financial indicator, people were better off when he left office than when he entered it. ${ }^{47} \mathrm{He}$ tries strongly to argue that his Government did not just ride an inevitable economic wave built on the mining boom, but that it helped to foster those good economic times through taxation reform and balanced budgets. Howard also insists that people were not left behind, but that there was a 'human dividend' to lower unemployment and a strong safety net. ${ }^{48}$ Giving oneself a self-satisfied pat on the back is a frequent aspect of political memoirs, and can be found in those of both Menzies and Page. Politicians want to demonstrate to the general public that, in the words of Sir Humphrey, they have had achievements, not just engaged in activity. Howard, however, seems to be trying to demonstrate not only that he provided good government, but also that his achievements provide a model of good practice for future leaders.. Howard is trying to cultivate one very specific audience for his book, and that is the Liberal Party itself. The book is laced with lessons about the pleasures and the importance of being involved in campaigns as a Young Liberal, how perseverance in securing a parliamentary seat was rewarded even after several rejections, the need for healthy internal debate within the Liberal Party and the importance of keeping a good relationship with the

\footnotetext{
${ }^{47}$ Howard, Lazarus Rising, 530-47.

${ }^{48}$ Howard, Lazarus Rising, 658.
} 
Nationals. Ultimately, he paints himself as the patriarch of a strong and united Liberal Party which Howard believes did great things before him and will go on to do great things after him. The occasional commentary on contemporary issues shows how much Howard views his life as part of an ongoing partisan fight. His concluding chapter focuses very heavily on the Liberal Party, its philosophical basis, the need to maintain harmony between its liberal and conservative traditions and the need for plebiscite reform to attract more members. More remarkably, the last paragraph of the book places thankyous to Howard's family side by side with one to the Liberal Party. ${ }^{49}$

The enduring image provided by Lazarus Rising is of a political 'hero', but one tied inextricably to the party on which his success was based. Howard's emotional attachment to the Liberal Party is embodied in his deep admiration for Robert Menzies. Such a focus on the qualities of leaders is an aspect of liberalism's individualism and the subsequent tendency to interpret history through the actions of great individuals. Even in Lazarus Rising Howard seems to be trying to place himself in line of 'apostolic succession' from his party's founder. Menzies and the Menzies Government are mentioned more than twenty times, frequently in discussions relating to events after Menzies' death. For example, when discussing issues surrounding the leadership handover, Howard partially censures Costello for not following the 'Harold Holt' approach of waiting until his leader chose to retire. ${ }^{50}$ Here Howard is making a direct comparison between himself and Menzies, though he still insists that Costello had the right to challenge him so long as he did it openly. On another occasion Howard daydreams of being given an electoral gift as grand as the great Labor split. ${ }^{51}$

Howard on Menzies

\footnotetext{
${ }^{49}$ Howard, Lazarus Rising, 658.

${ }^{50}$ Howard, Lazarus Rising, 608.

${ }^{51}$ Howard, Lazarus Rising, 616.
} 
Howard's attachment to Menzies comes in large part from his childhood, or, at least, his remembered childhood. Howard grew up in the Menzies era with parents who were members of the 'Forgotten People' and who quickly developed an attachment to the Liberal Party after its founding in 1944. Menzies came to power for the second time in 1949 when Howard was ten; the life of the Menzies Government coincided with Howard's teenage and young adult years. Howard enjoyed his youth and admired his parents, so it was easy to attach positive emotions to Menzies as the man who personified the era. Howard has consistently viewed the prosperity and social stability of the Menzies era as achievements for emulation by governments. So well-known was Howard's devotion to Menzies, that in 1992 Paul Keating singled out the then Member for Bennelong to attack his fond memories of the 1950s. Rather than the 'golden age' of Howard's memory, Keating suggested that the 1950s had been a decade of stagnation during which 'Australia was injected with a near-lethal dose of fogeyism'. 52

This and similar derisive comments about the Menzies era partly inspired Howard to write his 2014 book The Menzies Era: the years that shaped modern Australia. The book seems to take an enduring negative image of Menzies as read, and rather than trying to debate a specific historian or historians it faces up against a more elusive popular image of the man, an image which it assumes is negative. Its bibliography is notably limited, deliberately avoiding the intricacies of academic journals in favour of the clear narratives generally offered by single or dual-authored books. ${ }^{53}$ This is a reflection of both the author's tastes and the books intention to itself provide a clear narrative for easy consumption.

\footnotetext{
52 The Rt Hon. Paul Keating, MP, Commonwealth Parliament of Australia House of Representatives Debates, official Hansard, 1992. 27 February, 373.

${ }^{53}$ Compiled works appear only in limited numbers: John Howard, The Menzies Era: the years that shaped modern Australia (Sydney, Harper Collins, 2014) 649-654.
} 
As the title of the book, and the documentary Howard on Menzies: building modern Australia adapted from it, suggest, Howard's thesis is that the prosperity and to a large extent the culture of modern Australia are built on the back of the achievements of the Menzies era. Nick Cater of the Menzies Research Centre has also been heavily involved in an attempt to resurrect Menzies' reputation, both in prompting an edited book which includes a chapter by Howard, and in helping the production of the documentary. ${ }^{54}$ One might even say that this is a continuation of the culture and history wars of the Howard era.

Since it is aiming to build up Menzies' achievements and legacy, Howard's book is essentially self-justification by proxy. Having retired at the height of his powers, Menzies never felt the need to justify his legacy to the same extent as Howard did in Lazarus Rising. With the Menzies legacy under significant criticism, Howard felt the need to offer the justification that Menzies never did. In so doing Howard is not only defending his idol but also the legacy and greatness of the Liberal Party to which his own achievements are inherently tied.

Howard's attempt to do what Menzies did not do is clearly shown by the political nature of the book. The book begins with a dedication to the branch members of the Liberal Party. This is followed by a foreword where Howard explains that the idea for the book came from Geoffrey Blainey who had explicitly suggested that Howard could bring a 'political perspective' to an understanding of Menzies. ${ }^{55}$ The book offers a deliberately Liberal Party view of its central subject. Minimal biographical information is provided on Menzies. His time as a Nationalist Party activist is largely brushed over. The Menzies of the book only really begins at the tail end of the United Australia Party. It becomes necessary to begin the proper narrative at this point for two reasons. One is that Menzies becomes prime minister for

\footnotetext{
${ }^{54}$ J R Nethercote (Editor), Menzies: The Shaping of Modern Australia (Brisbane: Connor Court, 2016).

${ }^{55}$ Howard, The Menzies Era, 1.
} 
the first time as a member of the United Australia Party in 1939. The other is that the birth of the Liberal Party is inextricably tied to the collapse of the United Australia Party. Essentially, the Menzies of The Menzies Era is born with the Liberal Party. It is the Party which is Howard's main concern and Menzies is portrayed essentially as the embodiment of that entity.

After a couple of introductory chapters, the book hits its straps with the election victory of 1949. Then it becomes a somewhat detailed account of twenty three years of Liberal rule. Essentially it is a work for popular consumption. Arguments are made about the importance and legacy of events, and there is a heavy focus on individual figures. Individuals are invariably introduced with an account of their personality and historical importance. For example Billy Hughes, who plays only a secondary role in a book focused on Menzies' time in power after 1949, is introduced with a brief biography of birthplace, occupation and role during the First World War. ${ }^{56}$ This indicates that Howard envisages a relatively uninformed audience. The focus on the interplay of such individuals is designed to provide a readable narrative for a general audience, while also showcasing the author's strengths in providing an insider's understanding of the behind the scenes interplay of politics.

Howard brings a personal perspective to the events of the Menzies era. The first chapter is an exercise in cultural history, highlighting the differences between the past and the present within the context of Howard's childhood in Earlwood. Throughout the book the regular narrative is frequently interrupted to offer the author's personal experience of an event or to link something to a contemporary issue. This personalisation of the past is nothing new for Howard. Judith Brett has highlighted the fact that even as prime minister, Howard would personalise speeches with references to his childhood and lived experiences. ${ }^{57}$ This could reflect a new focus on identity as a basis for political action, clearly traceable in the trend for

\footnotetext{
${ }^{56}$ Howard, The Menzies Era, 21-22.

${ }^{57}$ Brett, Australian Liberals and the Moral Middle Class, 211-2.
} 
maiden parliamentary speeches to be increasingly autobiographical. ${ }^{58}$ This adds personal emotional depth to what could be dry history. It also offers some justification for Howard's authorship. After all, what would be the point of having Howard write about Menzies if the work was not laced with Howard's unique perspective?

Though Howard discusses the three prime ministers who followed Menzies, none of them are shown in an overwhelmingly favourable light. Holt's achievements and attempt to engage with Asia are discussed, but he is simply not around for long enough for a proper judgement to be formed. John Gorton is critiqued as someone who had tremendous gifts and the capacity for strong leadership, but ultimately proved to be his own worst enemy. ${ }^{59}$ Despite Howard's personal attachment to William McMahon as his one-time campaign staffer, 'Billy' is portrayed in the traditional manner as both unpopular and untrustworthy. Discussion of these Liberal leaders is justified on the basis of their continuation of the Menzies era, but their mediocre presence also helps to magnify the stable leadership of the towering figure that went before them. This only leaves Malcolm Fraser between Menzies and Howard as a Liberal Prime Minister. In Lazarus Rising Howard's attitude to Fraser is quite complex. On the one hand he sees Fraser as the appropriate leader for the time and emphasises his proper professional relationship with Fraser while noting that Fraser was 'a creature of the MenziesMcEwen period of economic management. ${ }^{60}$ Fraser comes across as too timid and traditional to change; perhaps, one might say, too much like Menzies.

Howard does acknowledge that the real parting of the ways only came when Howard was Prime Minister. However, one can see a division between the two men in the latter years of Fraser's Prime Ministership as Fraser resisted the need for changes in taxation and financial

\footnotetext{
${ }^{58}$ David McCooey \& David Lowe, “Autobiography in Australian parliamentary first speeches”, Biography: An Interdisciplinary Quarterly, 33, no. 1, (2010), 68-83.

${ }^{59}$ Howard, The Menzies Era, 514-48.

${ }^{60}$ Howard, Lazarus Rising, 135
} 
management. ${ }^{61}$ It was both personal and political. Although Howard had been Fraser's deputy and Andrew Peacock had challenged Fraser, Fraser gave Peacock the nod as his successor. In his memoirs he justifies his choice as follows: 'On issues I thought were important, on the core liberal values, I had learned to have confidence in Andrew's attitude. I had come to be not so confident of John's. ${ }^{62}$ Given such an attitude it is not to be wondered that Howard did not include Fraser as a Liberal great.

In the documentary Howard even describes Menzies as a 'colossus' bestriding every scene. ${ }^{63}$ Much as he might claim objectivity, in reality Howard is constructing Menzies as a hero for the Liberal Party. He does so not through hagiography, as this would be too transparent, but through level-headed judgements that make Howard's appreciation of Menzies all the more convincing. His motivation for doing so is based on his deep admiration for the man and for the Liberal Party, but it is also a conscious attempt to emulate the Labor Party. The Australian Labor Party and its supporters have long had a tradition of writing books and composing epic histories which have eclipsed anything on the non-Labor side of politics. Biographies of Whitlam, Chifley and Curtin are multiple, whereas non-Labor figures are lucky to be given the attention of a single solid book. Similarly, histories of the Labor Party abound to a far greater extent than those of the Liberals, so much so that some have become highly specific. ${ }^{64}$ Howard has been quite explicit on the need for Liberals to emulate the intellectual vigour of their opponents. In a recent interview given at the Sydney premiere of Howard on Menzies, Howard declared that it was not enough for Liberals to complain that there were more Labor Party books and that Labor dominated the intelligentsia, it was up to Liberals to go out and

\footnotetext{
${ }^{61}$ Howard, Lazarus Rising, 124ᄀ36

${ }^{62}$ Malcolm Fraser and Margaret Simons, Malcolm Fraser: The Political Memoirs, (Melbourne: Miegunyah Press, 2015), 616 7

${ }^{63}$ Howard on Menzies: building modern Australia, Director Simon Nasht, Producer Ruth Cross (Australia, 2016).

${ }^{64}$ E.g. Michael Hogan, Local Labor: A History of the Labor Party in Glebe 1891-2003 (Sydney: Federation Press, 2004).
} 
fill the gap. ${ }^{65}$ This also fits the agenda of Nick Cater, who has been moving the Menzies Research Centre into a historical battleground that it has not occupied previously.

There are manifest reasons why Howard wants to catch up to Labor. If there is an intellectual lag between the Liberals and Labor, that could prompt a leaching of talent towards their opposition. Those with an intellectual curiosity and an appetite for reading need to be offered alternate fare or they will be forced to read, and be influenced by, the books of the left. Howard is keenly aware of the emotional pull of history as can be seen by the Australian History Summit in 2006 and his fondness for historians such as Les Carlyon. As prime minister, Howard was associated with a revival of the ANZAC legend and Australian nationalism. He has even been accused of having successfully co-opted the language of Russel Ward's Australian Legend for the conservative cause. ${ }^{66}$ Howard understands that history has the power to inspire and he wants it to inspire people to become actively involved in the Liberal Party to which he remains extremely devoted. This competition of ideas also explains why the Menzies Research Centre is so keen to place copies of the Menzies DVD into schools. ${ }^{67}$

There is also a more personal, perhaps even selfish, motive for building up the Liberal past. Howard's achievements will appear greater if they are placed in the context of a great Liberal movement. This is because he can then be judged not just on the economy and various individual policies, but on the way he built on his predecessors' achievements and made his party a success. Labor Party history suggests that such criteria for judgement are easier to fulfil. Labor Party figures can win praise amongst their supporters simply by kneeling at the

\footnotetext{
${ }^{65}$ John Howard, Interview at Howard on Menzies Sydney Premiere run by the Menzies Research Centre, 13/9/2016.

${ }^{66}$ Brett, Australian Liberals and the Moral Middle Class, 202-6.

${ }^{67}$ Nick Cater, 'Put Menzies in the School Curriculum.' https://www.menziesrc.org/news/item/put-menzies-onthe-school-curriculum Accessed 24 November, 2016.
} 
altar of Ben Chifley and Gough Whitlam. John Howard is deliberately constructing an altar to Robert Menzies, perhaps in the hope that one day Liberal writers will build one for him. Such egotistical aggrandisement is not necessarily a part of the story, it could still be that the emotional investment Howard has in Menzies is what motivates him to build his hero up and connect, as much as possible, himself to the achievements that even as an adolescent he admired. What is clearer is that through both Lazarus Rising and The Menzies Era, Howard is trying to build up a personal narrative for the Liberal Party which his predecessor and idol never imagined. 